\title{
ISKUSTVA KLINIKE ZA ONKOLOGIJU I RADIOTERAPIJU U KONKOMITANTNOJ KEMORADIOTERAPIJI NESITNOSTANIČNOG RAKA PLUĆA TRODIMENZIONALNOM KONFORMALNOM TEHNIKOM - DOZIMETRIJSKA STUDIJA
}

\author{
VIDE VULETIĆ ${ }^{1}$, DARIJO HREPIĆ ${ }^{1,2}$, TIHANA BORASKA JELAVIĆ 1,2
}

Cilj: Ispitati dozimetrijske trendove na organe od rizika i akutnu toksičnost u pacijenata s karcinomom pluća nemalih stanica liječenih trodimenzionalnom konformalnom kemoradioterapijom u jednom onkološkom centru.

Metode: Ovo je retrospektivna studija provedena na Klinici za onkologiju i radioterapiju KBC-a Split. Prikupljeni su podatci oboljelih od lokalno uznapredovalog nesitnostaničnog karcinoma pluća liječenih trodimenzionalnom konformalnom radioterapijom od 2011. godine do početka 2019. godine. Prikupljeni su podatci pacijenata koji su se zračili primarno, adjuvantno i/ili neoadjuvantno. Uključeni pacijenti primili su najmanje jedan ciklus kemoterapije. Ciljni volumeni i organi od rizika ocrtani su prema radioterapijskim smjernicama.

Rezultati: Medijan doze na "planing treatment volume” bio je 56 Gy. Najčešća akutna radijacijska toksičnost bila je akutni ezofagitis. Nije zabilježen nijedan slučaj akutnog radijacijskog pneumonitisa. Nije pokazana korelacija između prekoračenja doze na zadane volumene organa od rizika i toksičnosti istih, te smo ukazali na trend poboljšanja dozimetrijskih rezultata kroz godine liječenja.

Zaključak: Toksičnost liječenja 3D KRT-om lokalno uznapredovalog raka pluća u Klinici za onkologiju i radioterapiju KBC-a Split usporediva je s objavljenim rezultatima drugih svjetskih institucija. S duljim vremenom primjene trodimenzionalne konformalne radioterapije u kliničkoj praksi postiže se optimalna raspodjela doza zračenja na rizične organe.

Ključne riječi: NESITNOSTANIČNI RAK PLUĆA, RADIOTERAPIJA, TRODIMENZIONALNA KONFORMALNA RADIOTERAPIJA, KONKOMITANTNA KEMORADIOTERAPIJA, TOKSIČNOST, DOZIMETRIJA

\section{UVOD}

Nakon bolesti kardiovaskularnog sustava rak je najznačajniji uzrok smrti u Hrvatskoj, a u 2015. godini incidencija malignih bolesti iznosila 535,55/100 000 (2). U muškaraca je po incidenciji na prvom, a u žena na četvrtom mjestu, dok je po mortalitetu na prvom mjestu u muškaraca i trećem u žena (1). Od 2001. do 2015. godine, ukupan broj novodijagnosticiranih slučajeva karcinoma plu-

${ }^{1}$ Klinika za onkologiju i radioterapiju, KBC Split ${ }^{2}$ Sveučilište u Splitu,

Sveučilišni odjel zdravstvenih studija

Adresa za dopisivanje:

Doc. dr. sc. Tihana Boraska Jelavić, dr. med.

Klinika za onkologiju i radioterapiju, KBC Split

21000 Split, Spinčićeva 1

E-mail: tihana_boraska@yahoo.com; tbjelavic@ozs.unist.hr ća se smanjio za 15\%; usprkos tome, u 2021. godini Hrvatska se s incidencijom karcinoma pluća od 34,3/100 000 nalazila među 20 zemalja svijeta s najvišom incidencijom $(2,3)$.

Nesitnostanični karcinomi pluća čine otprilike $85 \%$ svih karcinoma pluća, s petogodišnjim preživljenjem od samo $1 \%(4,5)$. Ostatak od $15 \%$ su sitnostanični karcinomi pluća.

Uz kiruršku i sistemsku antitumorsku terapiju, radioterapija je jedan od tri glavna načina liječenja karcinoma pluća. Pripada lokalnim metodama liječenja, a koriste se uglavnom teleterapijski uređaji (prvenstveno linearni akcelerator) s izvorima zračenja megavoltnih (MV) energija.
Današnji minimalni standard $u$ provođenju teleradioterapije raka pluća jest trodimenzionalna konformalna radioterapija (3D KRT) koja se temelji na simulacijskom snimku pacijenta kroz područje od interesa kompjutoriziranom tomografijom ("computed tomography", CT) (6). Uz ocrtavanje ciljnih volumena (područja makroskopski i mikroskopski proširenog tumora), ocrtavaju se i organi od rizika (pluća, srce, jednjak, leđna moždina, veliki dišni putevi, brahijalni pleksus) kako bi ih uključili u izračun toksičnosti liječenja radioterapijom. Za procjenu razvoja moguće toksičnosti nam služi QUANTEC (Quantitative Analyses of Normal Tissue Effects in the Clinic) tablica koja se temelji na rezultatima znanstvenih istraživanja koja su za cilj imali ispitati vezu između veliči- 
na zračenih volumena organa od rizika, primijenjene doze zračenja i toksičnosti liječenja. Iako većina parametara (odnos volumena i vjerojatnosti razvoja određene toksičnosti) nije strogo definirana i nema točno određenu granicu, ipak postoje određeni trendovi koji mogu služiti kao smjernice pri planiranju radioterapije (7). Najvažniji organi od rizika $\mathrm{u}$ provođenju torakalne radioterapije su pluća, jednjak, srce i leđna moždina, za koje postoji razrađen QUANTEC sustav $(8,9)$.

U našem smo radu analizirali radioterapijske dozimetrijske planove bolesnika liječenih torakalnom konkomitantnom kemoradioterapijom lokalno uznapredovalog raka pluća u Klinici za onkologiju i radioterapiju, u vremenu od 2011. godine, kada smo uveli 3D KRT, do početka 2019. godine. Cilj rada je bio provjera dozimetrijskih parametara na ciljne i organe od rizika, te korelacija isporučenih doza zračenja s opaženom toksičnošću liječenja. Praćenjem dozimetrijskih parametara izrađenih radioterapijskih planova nastojali smo istražiti trendove kvalitete planova kroz godine praćenja. kao odraz akumuliranog iskustva primjene 3D KRT-a našeg cjelokupnog radioterapijskog tima.

\section{METODE I MATERIJALI}

Ova retrospektivna studija je provedena na Klinici za onkologiju i radioterapiju Kliničkog bolničkog centra Split, uz dopuštenje Etičkog povjerenstva navedene ustanove. Podatci su prikupljeni iz povijesti bolesti pacijenata oboljelih od nesitnostaničnog karcinoma pluća, liječenih 3D KRT-om konkomitantno s kemoterapijom, od početka primjene navedene tehnike zračenja u 2011. godini do početka 2019. godine. Uključeno je 100 pacijenata kojima je terapija bila ili primarna ili adjuvantna ili neodjuvantna. Pacijenti uključeni u studiju primili su najmanje jedan ciklus kemoterapije konkomitantno s radioterapijom.

Svi ispitanici prezentirani su na multidisciplinarnom timu prije odluke o liječenju.

Ispitanici su bili simulirani na $\mathrm{CT}$ simulatoru Toshiba Aquillion LB, a zra- čeni 3D tehnikom na linearnom akceleratoru (Linac, Elekta, Sweden) fotonima visokih energija (6 i $18 \mathrm{MV}$ ), 5 dana u tjednu, izuzev vikenda i blagdana, s dnevnom frakcijom od 2 Gy na dan do ukupne terapijske doze po izboru liječnika. Cilj su bile doze od 60 do 66 Gy koje su modificirane $\mathrm{u}$ odnosu na postignute doze tolerancije za organe od rizika, odnosno u tijeku liječenja prema toksičnosti terapije. Kao organi od rizika u svih pacijenata konturirani su: srce, pluća, jednjak te leđna moždina. Doze tolerancije za organe od rizika određene su prema smjernicama QUANTEC-a (10). Glavni analizirani parametri bili su medijan doze na PTV, srednja doza na ukupni volumen pluća-PTV, V20 za pluća, srednja doza na ukupni volumen srca, V46 za srce, srednja doza na ukupni volumen jednjaka, V35, V50 i V70 za jednjak i maksimalna doza na leđnu moždinu. Konkomitantno sa zračenjem aplicirala su se do dva ciklusa kemoterapije po PE protokolu. PE protokol podrazumijeva davanje dva lijeka, cisplatina i etopozida, intravenski paralelno uz premedikaciju i simptomatsku terapiju. Etopozid se osim intravenski kod nekih pacijenata davao i peroralnim putem. Koristili smo dvije varijante PE protokola, trodnevnu i petodnevnu. Trodnevni protokol je uključio primjenu cisplatina u dozi od $60-80 \mathrm{mg} /$ $\mathrm{m}^{2}$ prvi dan ciklusa, te etopozida od 100 $\mathrm{mg} / \mathrm{m}^{2}$ intravenski prva tri dana ciklusa. Drugi ciklus se planirao 21. dan od početka prvog ciklusa, ovisno o toksičnosti i podnošljivosti terapije. Petodnevni protokol je uključio primjenu cisplatina u dozi od $50 \mathrm{mg} / \mathrm{m}^{2}$ prvi i 8 . dan ciklusa, te etopozida od $50 \mathrm{mg} / \mathrm{m}^{2}$ prvih 5 dana ciklusa. Drugi ciklus se planirao 28. dan od početka prvog ciklusa, ovisno o toksičnosti i podnošljivosti liječenja.

\section{STATISTIČKI POSTUPCI}

Povezanost između prekoračenja doze zračenja na organe od rizika od preporučenih vrijednosti i pojavnosti zabilježenih nuspojava liječenja testirala se Hi kvadrat testom, dok se u slučaju neispunjenja preduvjeta za provedbu Hi kvadrat testa koristio Fisherov egzaktni test. Trend kretanja prekoračenja preporučenih vrijednosti doze zračenja na organe od rizika u Gy, kroz godine primjene opisane tehnike zračenja, procjenjivao se upotrebom linearnog trend modela. Od metoda deskriptivne statistike doze zračenja na organe od rizika i PTV izražene su medijanom vrijednosti s naznačenim interkvartilnim rasponom (IQR, Q1-Q3). Analiza je rađena u statističkom softwareu STATISTICA 12, dok su se zaključci donosili pri razini značajnosti od 5\%.

\section{REZULTATI}

Analiza je napravljena na dozimetrijskim podatcima 100 zračenih bolesnika. Srednja vrijednost doze na PTV je iznosila 56 Gy s interkvartilnim rasponom vrijednosti od 50 Gy do 60 Gy. Izračunati su medijani doza (Tablica 1) i prekoračenja doze zračenja za volumen pluća minus PTV, volumen srca, jednjaka i leđne moždine.

Prekoračenje doze, definirano ako je na 30\% volumena pluća (V30) premašena doza od 20 Gy, utvrđeno je u 19 pacijenata $(19 \%)$. Prekoračenje doze, definirano ako je na $46 \%$ volumena srca premašena doza od 30 Gy (V46), utvrđeno je u 8 pacijenata (8\%). Prekoračenje doze na volumen jednjaka, definirano ako je primljena doza veća od 35 Gy na 50\% ukupnog volumena jednjaka (V35), utvrđeno je u 33 pacijenta (33\%). Prekoračenje V50 parametra na jednjaku je utvrđeno u 19 pacijenta (19\%). Prekoračenje V70 parametra na jednjaku nije bilo prisutno u niti jednog pacijenta. Maksimalna dozvoljena vrijednost na ukupan volumen leđne moždine od 50 Gy nije zabilježena ni u jednog pacijenta.

\section{Radijacijska toksičnost liječenja}

Različite plućne nuspojave utvrđene su u 4 pacijenta (4\%), međutim u niti jednoga se nije radilo o radijacijskom pneumonitisu. Nuspojave su bile: pleuralni izljev, dispneja, radijacijski medijastinitis i hemoptiza. Srčane nuspojave razvila su 2 pacijenta ( $2 \%)$, međutim u niti jednoga nije došlo do radijacijskog perikarditisa, već do radijacijskog medijastinitisa i sinkope. Radijacijski ezofagitis je utvrđen u 48 pacijenta (48\%), od toga u $44(91,7 \%)$ stupnja 1 i 2 , i u 4 pacijenta stupnja 3 $(8,3 \%)$. Nuspojave na leđnoj moždini nisu utvrđene u niti jednoga pacijenta. 
Tablica 1.

Medijani doza na organe od rizika

\begin{tabular}{|c|c|c|c|}
\hline Organ & Volumen (\%) & Medijan doze na volumen (Gy) & IQR (Interkvartilni raspon, Q1-Q3) \\
\hline Leđna moždina & Mean & 38,5 & $15,69-46,60$ \\
\hline \multirow[t]{4}{*}{ Jednjak } & Mean & 22,84 & $8,44-31,99$ \\
\hline & 50 & 13,10 & $2,45-42,40$ \\
\hline & 40 & 31,35 & $8,20-47,35$ \\
\hline & 20 & 46 & $18,60-53,80$ \\
\hline \multirow[t]{2}{*}{ Srce } & Mean & 4,84 & $0,95-14,84$ \\
\hline & 46 & 1,55 & $0,50-12,50$ \\
\hline Pluća minus PTV & Mean & 11,74 & $6,29-15,60$ \\
\hline Pluća & 30 & 11 & $3,95-19,15$ \\
\hline
\end{tabular}

Odnos toksičnosti i prekoračenja doza

Za 8,06 \% je veća zastupljenost pacijenata koji su imali prekoračenje doze zračenja na ukupan volumen pluća minus PTV i razvili su plućne nuspojave, $\mathrm{u}$ odnosu na zastupljenost pacijenata koji nisu imali prekoračenje doze na volumen pluća, a razvili su nuspojave. Testiranjem nije utvrđena povezanost između toksičnosti i prekoračenja doze $(p=0,162)$.

Za 11,41 \% je veća zastupljenost pacijenata koji su imali prekoračenje doze na volumen i razvoj neočekivanih nuspojava na srcu, u odnosu na zastupljenost pacijenata koji nisu imali prekoračenje doze na volumen srca, a razvili su nuspojave. Testiranjem nije utvrđena povezanost između toksičnosti i prekoračenja doze na volumen srca $(p=0,154)$.

Za 3,8\% je manja zastupljenost pacijenata koji su imali prekoračenje doze V35 na volumen jednjaka i razvoj očekivanih nuspojava na jednjaku (ezofagitis bilo kojeg stupnja), te za 7,27\% je manja zastupljenost pacijenata koji su imali prekoračenje doze na volumen jednjaka V50 i razvoj očekivanih nuspojava na jednjaku (ezofagitis bilo kojeg stupnja), u odnosu na zastupljenost pacijenata koji nisu imali prekoračenje doze na volumen jednjaka, a razvili su nuspojave. Testiranjem nije utvrđena povezanost između toksičnosti i prekoračenja doze na volumen V35 ( $p=0,721)$, kao ni na volumen V50 $(\mathrm{p}=0,568)$.
Trendovi prekoračenja doze na rizične organe

Analizom dozimetrijskih parametara bolesnika liječenih u vremenskom razdoblju od 2012. do 2019. godine utvrdili smo da je liječenje s barem jednim prekoračenjem doze u najvećem udjelu bilo zastupljeno u 2012. godini, kada su sva liječenja imala barem jedno prekoračenje. Prema procijenjenom modelu, u ishodišnoj se 2012. godini očekuje 85,76\% prekoračenja kod liječenja općenito, te se u svakom narednom razdoblju očekuje pad u prosjeku od $4,21 \%$ u svakoj narednoj godini. Trend kretanja prikazan je grafički (Slika 1).

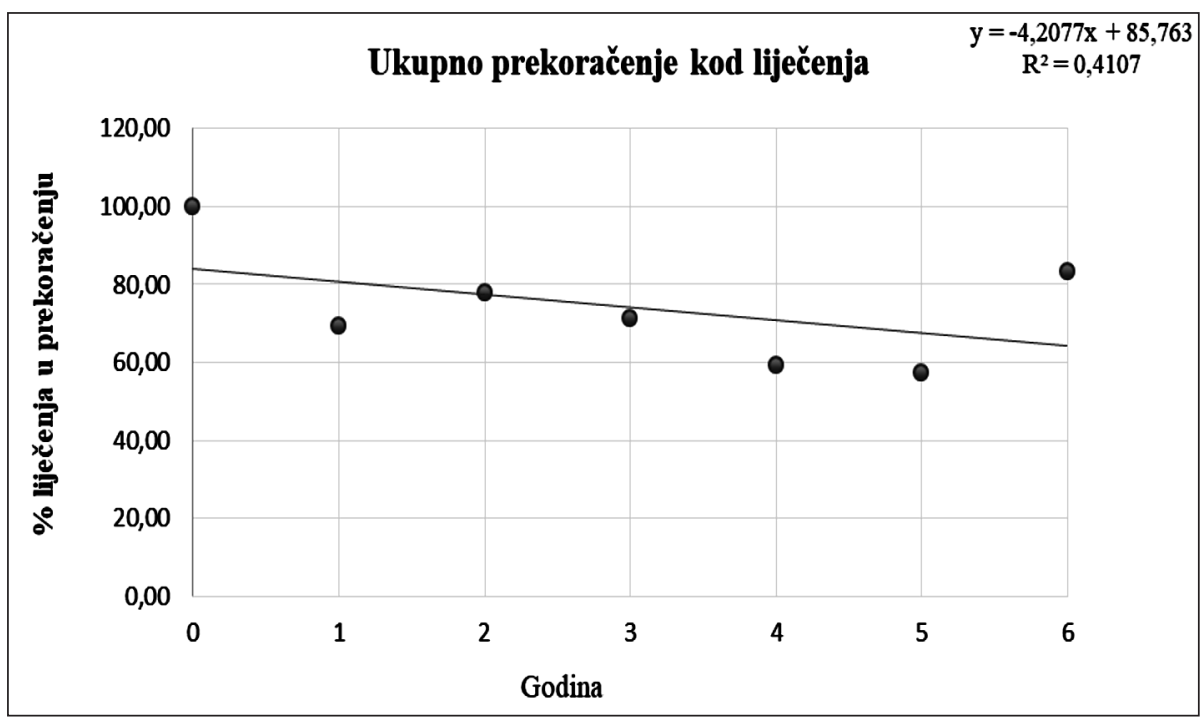

$\mathrm{x}=$ varijabla vremena, $\mathrm{y}=$ parametar/vrijeme, $\mathrm{R}^{2}=$ koeficijent determinacije

Slika 1.

Trend kretanja ukupne zastupljenosti prekoračenja doze na rizične organe

\section{RASPRAVA}

U Klinici za onkologiju i radioterapiju KBC-a Split proveli smo retrospektivno istraživanje na 100 pacijenata oboljelih od nesitnostaničnog raka pluća koji su liječeni konkomitantnom kemoradioterapijom (uključeni su pacijenti liječeni primarno, adjuvantno ili neoadjuvantno). Prikazali smo rezultate prekoračenja doze na organe od rizika i korelirali ih s opaženom akutnom toksičnošću liječenja.

Kod naših pacijenata je pronađeno prekoračenje od 20 Gy na ukupni volumen pluća u 19 (19\%) pacijenata. QUANTEC tablica predviđa 20\%-tni rizik 
nastanka radijacijskog pneumonitisa (RP), ako srednja doza na ukupni volumen pluća prijeđe 20 Gy (10). Wang i suradnici su u svom istraživanju iz 2006. godine retrospektivno evaluirali 223 pacijenta liječena KKRT-om. Prekoračenje doze parametra V20 je postojalo kod 30 pacijenata $(13,5 \%)$, no pokazali su da je V5 bio najbitniji čimbenik razvoja toksičnosti te je kod tog parametra incidencija RP-a 22\% nakon 6 mjeseci, te $32 \%$ nakon jedne godine, na medijan praćenja pacijenata od 10,5 mjeseci (11). Vremensko praćenje naših ispitanika je bilo 2 mjeseca nakon završetka primarnog liječenja u očekivanju akutne toksičnosti koja se najviše tada razvija i jer smo do tada imali potpunu medicinsku dokumentaciju. Nismo pronašli niti jedan slučaj RP-a kod naših ispitanika, što , među ostalim, možemo pripisati manjem medijanu doze na PTV; medijan je iznosio 56 Gy (raspon 50 Gy - 60 Gy), dok je kod Wanga medijan bio 63 Gy (raspon 50,4 - 69,6 Gy) (11). Kim i suradnici u svome istraživanju analizirali su 76 pacijenata liječenih 3D RT od raka pluća te ustanovili razvoj RP-a 1. stupnja kod 23 pacijenta (30\%), RP 2. stupnja kod 11 pacijenata (14\%), RP 3.stupnja kod 11 pacijenata (14\%), te RP 4 . stupnja kod 1 pacijenta (1\%). Medijan doze na volumen je bio 60 Gy (raspon 56 Gy -66 Gy), što je opet veća doza na PTV u odnosu na naš medijan doze, što može objasniti činjenicu da u našem istraživanju nismo zabilježili takvu toksičnost (12). Ovi autori su usporedbom razvoja RP i primijenjene doze zračenja testirali različite parametre: srednja doza na pluća (mean), V20, V30, V40 i V50, te pokazali najveću korelaciju razvoja RP-a kod parametara srednja doza na pluća, V20 i V30. Manje od 10\% ispitanika je razvila RP 2. stupnja kod srednje doze na volumen pluća od 20 Gy.(12) Hernando je u radu iz 2001. godine analizirao 201. pacijenta s rakom pluća liječenih 3D KRT-om, te pronašao da je 39 pacijenata (19\%) razvilo RP; od toga 4 pacijenta 1. stupnja, 27 pacijenata 2 . stupnja i 8 pacijenata 3 . stupnja. RP se razvio u $10 \%$ pacijenata sa srednjom dozom na pluća manjom od $10 \mathrm{~Gy}$, kod $16 \%$ pacijenata sa srednjom dozom na pluća od 21-30 Gy, te kod 27\% pacijenata sa srednjom dozom na pluća od >30 Gy (13).
Radijacijski ezofagitis (RE) je bio najučestalija toksičnost $\mathrm{u}$ našem istraživanju; razvio se u 48\% bolesnika, od toga u većini stupnja 1 i 2. Maguire je u svome istraživanju iz 1999. godine ispitao 91 pacijenta liječenog 3D KRT-om s medijanom doze na PTV od 78,8 Gy (raspon 64,2 Gy - 85,6 Gy). Niti jedan pacijent nije razvio radijacijski ezofagitis (RE) stupnja toksičnosti 4. i 5., iako je medijan doze na PTV bio visok, ali je pronašao da je 10 pacijenata razvilo RE 3. stupnja, bez ikakve korelacije s dozom na ukupni volumen jednjaka. Njihova analiza je pokazala da je parametar od $<50$ Gy na 32\% ukupnog volumena jednjaka najznačajniji pokazatelj razvijanja RE bilo kojeg stupnja (14). Mi smo se vodili QUANTEC parametrima i istraživali smo toksičnost na jednjak kod V35, V50 i V70, te smo pronašli najveće prekoračenje kod parametara V35 i V50 (7). Od 48 pacijenata s razvijenim RE bilo kojeg stupnja, 33 pacijenta su imala prekoračenje doze od 35 Gy na više od 50\% ukupnog volumena jednjaka, dok je 15 pacijenata ostalo unutar QUANTEC-om predviđene tablice. QUANTEC tablica predviđa pojavnost RE 2. stupnja na manje od $30 \%$ pacijenata s prekoračenom dozom od 35 Gy na 50\% ukupnog volumena jednjaka (10). Kod većine naših pacijenata, 44\%, RE je bio 1. i 2. stupnja toksičnosti, dok je stupanj 3 zabilježen kod $4 \%$ pacijenata. Kako je gotovo polovica bolesnika (njih 21/48, 43,7\%) imala stupanj toksičnosti 1, analiza odnosa volumen-doza-toksičnost ostaje izvan obuhvata QUANTEC tablice, odnosno zaključujemo da izazvana toksičnost nije viša od očekivane. Nadalje, od istih 48 pacijenata $\mathrm{s}$ razvijenim $\mathrm{RE}$, samo ih je 8 prekoračilo parametar od više od 50 Gy na 40\% ukupnog volumena jednjaka. Kako u tom slučaju QUANTEC tablica predviđa rizik razvoja RE do $30 \%$ pacijenata, sa svojih dobivenih $8 \%$ smo čvrsto unutar tolerancije i prediktabilnosti razvoja neželjene posljedice. Zadnji QUANTEC parametar predviđa da će manje od 30\% pacijenata razviti RE 2. stupnja ako doza na ukupni volumen jednjaka od $20 \%$ prijeđe više od 70 Gy (46), a u tom parametru nismo zabilježili niti jedno prekoračenje doze.
Kim je u svome radu iz 2005. ispitao 124 pacijenta, od kojih su 74 pacijenta bila liječena konkomitantnom kemoradioterapijom, te je 5 od 44 pacijenata $(11,3 \%)$ razvilo RE 3 . stupnja kod V $60 \leq 30 \%$, a 10 od 30 pacijenata $(33,3 \%)$ je razvilo RE 3. stupnja kod V60>30\%, i zaključio da je V60 kod konkomitantne kemoradioterapije najtočniji za prediktabilnost razvoja toksičnosti jednjaka (15). Od 48 pacijenata s RE-om, u našem istraživanju samo su 4 pacijenta razvila stupanj toksičnosti $3(8,3 \%)$, a nije zabilježen niti jedan slučaj RE stupnja 4 ili 5. Od Spierovih 251 pacijenta, 67,5\% pacijenata je razvilo RE stupnja 2, a 12,1\% RE stupnja 3 (16).

Srce se, kao jedan od organa od rizika pri planiranju 3D KRT-a, često stavlja unutar V30 parametra QUANTEC tablice koja pokazuje da postoji 15\% šanse za razvoj perikarditisa, ako doza na $46 \%$ ukupnog volumena srca prijeđe $30 \mathrm{~Gy}$ (10). Niti jedan od naših 100 ispitanika nije razvio perikarditis, unatoč tome što je 8 pacijenata primilo dozu veću od 30 Gy. Spiers je u svome radu ispitao 251 pacijenta (od toga 78\% liječenih KRTom) te opisao razvoj srčane toksičnosti kod 57\% pacijenata (2. stupnja 27,5\%, 3 . stupnja $24 \%$ i 5 . stupnja $0,2 \%$ ) kod medijana doze na PTV od 66 Gy (16).

Jedina smjernica koju Emami opisuje u svome radu i koju predlaže QUANTEC tablica jest da bilo koji volumen leđne moždine ne smije primiti više od 50 Gy; u našem radu nije zabilježen niti jedan takav slučaj, već je medijan doze na leđnu moždinu iznosio 38,5 Gy (raspon 15,69 Gy - 46, 60 Gy) (10). Medijan doze na planirani volumen u naših pacijenata je nešto niži od preporučenog u stručnim smjernicama, što je odraz realne kliničke prakse i retrospektivnog ustroja istraživanja.

Uvođenje nove tehnike liječenja u kliničku praksu uvijek ima određenu vremensku krivulju učenja onih koji je provode. 3D KRT je uvedena u našu ustanovu nakon cjelovite edukacije kompletnog radioterapijskog tima 2011. godine i označila je bitan iskorak u odnosu na dotadašnje standardno, konvencionalno 2D planiranje radioterapije. Dozimetrijska analiza isporučenih doza zračenja 
na organe od rizika kroz godine implementacije nove tehnike, u vremenu od 2011. do 2019. godine, pokazala je trend pada prekoračenja doza u našoj ustanovi od 4,21\% godišnje. Rezultat je to razvoja ekspertize u primjeni 3D KRT-a u Klinici za onkologiju i radioterapiju u Splitu u liječenju solidnih tumora općenito, pa tako i lokalno uznapredovalog raka pluća.

Limitirajući faktori studije su retrospektivni ustroj istraživanja, analiza toksičnosti iz medicinske dokumentacije pacijenata koja u realnim okolnostima nije uvijek potpuna, kao i nedostatak podataka kasne toksičnosti zbog ograničenog vremena praćenja bolesnika i gubitka pacijenata iz praćenja.

\section{ZAKLJUČAK}

Analiza dozimetrijskih podataka 100 bolesnika s nesitnostaničnim rakom pluća liječenih 3D KRT-om je pokazala da su stope prekoračenja doze zračenja na organe od rizika sukladne izvještajima drugih istraživača $i$ da nisu dovele do povećane akutne toksičnosti liječenja. S aspekta prekoračenja doza zračenja na organe od rizika, ona su u promatranom razdoblju primjene 3D KRT-a u našoj ustanovi bila značajno manja s godinama primjene tehnike.

\section{Kratice:}

PTV - planning treatment volume 3D KRT - trodimenzionalna konformalna radioterapija

KKRT - konkomitantna kemoradioterapija $\mathrm{RP}$ - radijacijski pneumonitis

$\mathrm{RE}$ - radijacijski ezofagitis

\section{NOVČANA POTPORA/FUNDING \\ Nema/None}

\section{ETIČKO ODOBRENJE/ETHICAL APPROVAL Nije potrebno/None}

SUKOB INTERESA/CONFLICT OF INTEREST Autori su popunili the Unified Competing Interest form na www.icmje.org/coi_disclosure.pdf (dostupno na zahtjev) obrazac i izjavljuju: nemaju potporu niti jedne organizacije za objavljeni rad; nemaju financijsku potporu niti jedne organizacije koja bi mogla imati interes za objavu ovog rada u posljednje 3 godine; nemaju drugih veza ili aktivnosti koje bi mogle utjecati na objavljeni rad./ All authors have completed the Unified Competing Interest form at www.icmje.org/coi_disclosure. $p d f$ (available on request from the corresponding author) and declare: no support from any organization for the submitted work; no financial relationships with any organizations that might have an interest in the submitted work in the previous 3 years; no other relationships or activities that could appear to have influenced the submitted work.

\section{LITERATURA}

1. Hrvatski zavod za javno zdravstvo, Registar za rak Republike Hrvatske. Incidencija raka u Hrvatskoj 2012., Bilten 37, Zagreb, 2014.

2. Siroglavić K-J, Polić Vižintin M, Tripković I, Šekerija M, Kukulj S. Trends in incidence of lung cancer in Croatia from 2001 to 2013: gender and regional differences. Croat Med J. 2017; 58 (5): 358-63.

3. Globocan 2012 / (Internet). (citirano 8. rujna 2021.)

4. Sher T, Dy GK, Adjei AA. Small cell lung cancer. Mayo Clin Proc. 2008; 83 (3): 355-67.

5. Navada S, Lai P, Schwartz AG, Kalemkerian GP. Temporal trends in small cell lung cancer: analysis of the national Surveillance Epidemiology and End-Results (SEER) database. J Clin Oncol. 2006; 24 (18): 384.

6. Burnet NG. Defining the tumour and target volumes for radiotherapy. Cancer Imaging. 2004; 4 (2): 153-61.

7. Bentzen SM, Constine LS, Deasy JO, Eisbruch A, Jackson A, Marks LB, et al. Quantitative Analyses of Normal Tissue Effects in the Clinic (QUANTEC): An Introduction to the Scientific Issues. International Journal of Radiation Oncology, Biology, Physics. 2010; 76 (3).

8. Atlases for Organs at Risk (OARs) in Thoracic Radiation. (Internet). (pristup 8. Rujna 2021.). Dostupno na: https://www.eviq.org.au/getmedia/a4c012a8-d6a7-4d87-93f7-d3f465b49889/ RTOG-heart-contouring-atlas.pdf.aspx?ext=. pdf

9. Graham MV, Purdy JA, Emami B, Harms W, Bosch W, Lockett MA, et al. Clinical dose-volume histogram analysis for pneumonitis after 3D treatment for non-small cell lung cancer (NSCLC). IJROBP. 1999; 45 (2): 323-9.

10. Emami B. Tolerance of Normal Tissue to Therapeutic Radiation. Reports of Radiotherapy and Oncology. 2013; 1 (1): 35-48.

11. Wang S, Liao Z, Wei X, Liu HH, Tucker SL, $\mathrm{Hu}$ C-S, et al. Analysis of clinical and dosimetric factors associated with treatment-related pneumonitis (TRP) in patients with non-smallcell lung cancer (NSCLC) treated with concurrent chemotherapy and three-dimensional conformal radiotherapy (3D-CRT). International Journal of Radiation Oncology, Biology, Physics. 2006; 66 (5): 1399-407.

12. Kim TH, Cho KH, Pyo HR, Lee JS, Zo JI, Lee DH, et al. Dose-volumetric Parameters for Predicting Severe Radiation Pneumonitis after
Three-dimensional Conformal Radiation Therapy for Lung Cancer. Radiology. 2005; 235 (1): 208-15.

13. Hernando ML, Marks LB, Bentel GC, Zhou S-M, Hollis D, Das SK, et al. Radiation-induced pulmonary toxicity: a dose-volume histogram analysis in 201 patients with lung cancer. International Journal of Radiation Oncology, Biology, Physics. 2001; 51 (3): 650-9.

14. Maguire PD, Sibley GS, Zhou S-M, Jamieson TA, Light KL, Antoine PA, et al. Clinical and dosimetric predictors of radiation-induced esophageal toxicity. International Journal of Radiation Oncology, Biology, Physics. 1999; 45 (1): 97-103.

15. Hardy D, Liu C- C, Cormier JN, Xia R, Du XL. Cardiac toxicity in association with chemotherapy and radiation therapy in a large cohort of older patients with non-small-cell lung cancer. Annals of Oncology. 2010; 21 (9): 1825-33.

16. Speirs CK, Dewees TA, Rehman S, Molotievschi A, Velez MA, Mullen D, et al. Heart Dose Is an Independent Dosimetric Predictor of Overall Survival in Locally Advanced NonSmall Cell Lung Cancer. Journal of Thoracic Oncology. 2017; 12 (2): 293-301. 


\section{Summary}

\section{EXPERIENCE OF DEPARTMENT OF ONCOLOGY AND RADIOTHERAPY IN THREEDIMENSIONAL CONFORMAL CHEMORADIOTHERAPY OF NON-SMALL CELL LUNG CANCER - DOSIMETRIC STUDY}

Vide Vuletić, Darijo Hrepić, Tihana Boraska Jelavić

Aim of the study: To investigate organs-at-risk toxicity with concomitant chemo radiotherapy in non-small cell lung cancer patients, and to explore dosimetry trends for organs-at-risk over the years. To investigate the rates of acute toxicities and to compare the results with the worldwide literature.

Subjects and methods: This is a retrospective study conducted at the Department of Oncology and Radiotherapy at University Hospital of Split. Data were collected from patients with locally advanced non-small cell lung cancer treated with three-dimensional conformal chemo radiotherapy from 2011 to early 2019. Data were collected from patients who were treated with primary, adjuvant, and/or neoadjuvant radiotherapy. The patients received at least one cycle of chemotherapy. The target volumes and organs of risk were delineated according to radiotherapy guidelines.

Results: The median dose on planning treatment volume was 56 Gy. The most common acute radiation toxicity was radiation esophagitis. No cases of acute radiation pneumonitis were noted. No correlation has been noted between dose override on organsat-risk volumes and toxicity, and we have shown a trend of improved dosimetry results through the years.

Conclusion: The toxicity of treatment with $3 D$ conformal radiotherapy for locally advanced lung cancer at the Department of Oncology and Radiotherapy at University Hospital of Split is comparable to the published results of other worldwide institutions. With longer use of $3 D$ conformal radiotherapy we have seen improved dosimetry results over the years.

\section{Keywords: NON-SMALL CELL LUNG CANCER, RADIOTHERAPY, THREE-DIMENSIONAL CONFORMAL RADIOTHERAPY, CONCOMITANT CHEMO RADIOTHERAPY, TOXICITY, DOSIMETRY}

Primljeno/Received: 12. 9. 2021.

Prihvaćeno/Accepted: 12. 11. 2021. 